\title{
ENTRE 0 IMPERATIVO DA RESISTÊNCIA E A CONSCIÊNCIA DA DERROTA: A LITERATURA BRASILEIRA DURANTE 0 REGIME MILITAR'
}

http://dx.doi.org/10.11606/issn.2237-1184.v0i23p232-243

Marcos Napolitano ${ }^{2}$

Universidade de São Paulo

\section{RESUMO}

Este artigo propõe uma cartografia geral para situar a literatura brasileira (prosa e poesia) dentro do campo mais amplo da chamada "resistência cultural" ao regime militar implantado em 1964. No plano da memória social, a literatura é pouco lembrada dentro do campo das artes, se compararmos aos papeis ocupados pelo teatro, música popular e cinema na constituição da identidade de oposição ao regime. Entretanto, a literatura deve ser analisada a partir de sua capacidade de adensamento das relações entre a linguagem reflexiva e a matéria histórica, menos comprometida com imposições de mercado ou de grande público. Neste sentido, há um corpus essencial de autores e de obras que desempenharam um papel importante tanto na reconstrução de subjetividades diante da experiência da derrota e do autoritarismo, quanto no escrutínio da nova realidade social e política imposta pelo regime militar.

\section{ABSTRACT}

This article situates Brazilian literature (prose and poetry) within the broader field of the so-called 'cultural resistance' to the military regime, which came into force in the country in 1964. In terms of the social memory that exists in relation to the construction of the identity of opposition to the military regime, the role played by literature is less well remembered than that of the theater, popular music and cinema. However, the role of literature in this context should be analyzed in terms of its capacity to consolidate the relationships between reflexive language and historical material, less committed to the demands of the market or large-scale audiences. In this sense, there exists an essential corpus of authors and works that played an important role, both in the reconstruction of subjectivities in the face of the experience of authoritarianism, and also in scrutinizing the new social and political reality imposed by the military regime.
PALAVRAS-CHAVE:

Regime Militar. aspectos culturais. Literatura e Política. Literatura e Resistência Cultural. História e Literatura. Literatura brasileira. anos 1970.

\section{KEYWORDS:}

Military Regime. cultural aspects. Literature and Politcs.

Literature and cultural resistance. History and Literature. Brazilian Literature. 1970s.

\footnotetext{
${ }^{1}$ Este artigo foi desenvolvido a partir de pesquisa apoiada pelo CNPq (Bolsa Produtividade em Pesquisa)

${ }^{2}$ Historiador e docente do Departamento de História da Universidade de São Paulo. 


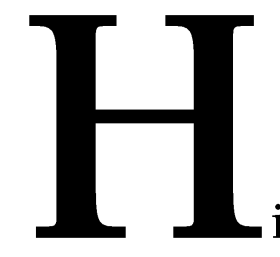

istória e Literatura: para além do documento

A literatura, historicamente falando, foi matriz e vetor na construção de perspectivas complexas e aprofundadas sobre experiências sociais, processos e eventos históricos nas mais diversas sociedades. Como "matriz", a literatura ajuda a forjar consciências e imaginários sobre o real, dando visibilidade e sentido às suas dimensões estruturais. Como "vetor", ela dissemina valores e posicionamentos ideológicos sobre a história e a sociedade na qual se insere. Estes aspectos não transformam a literatura em mero documento histórico, na expressão mais convencional e antiquada do termo, ou seja, expressão de uma voz não mediada de uma época. Tampouco anulam dimensões mais subjetivas e sublimes que se entretecem na experiência literária, seja na qualidade de autor ou leitor.

A literatura vista em seu conjunto - poesia ou prosa (ficcional, jornalística e testemunhal) transforma a matéria histórica em expressões formais. No entre-lugar destes polos - experiência histórica, matéria do real e expressão formal da palavra, forma-se uma consciência, pretensamente totalizante ou explicitamente fraturada. É a partir desta perspectiva que pretendo discutir o papel da literatura brasileira, com foco no campo da prosa ficcional, como formuladora de narrativas que sintetizaram os dilemas dos setores progressistas e de esquerda durante o regime militar. Em outras palavras, pretendo examinar o papel da literatura diante de uma experiência histórica específica - a ditadura militar brasileira entre os anos 1960 e 1970 - dando ênfase às maneiras como autores e obras lidaram com a derrota política, a violência de Estado e a resistência ao regime militar.

As relações entre literatura, violência e terrorismo de Estado no Brasil dos anos 1960 e 1970 já apresenta um "estado da arte" bem adensado que ilumina a forma como a matéria histórica se moldou como "fato literário" em diversas direções estéticas e ideológicas. Via de regra, os autores enfatizam os vários caminhos da militância literária ou a literatura como exercício da consciência e da subjetividade na luta contra o trauma e o silêncio impostos 
pela ditadura ${ }^{3}$. Sem prejuízo destas abordagens, meu objetivo é apontar para uma cartografia das produções literárias e seu sentido peculiar para a chamada "resistência cultural".

Frequentemente vista como fora do "primeiro plano" 4 diante da preponderância das artes de espetáculo no sistema cultural da resistência (cinema, música popular e teatro), a literatura foi, em minha opinião, o núcleo de expressão artística que examinou de maneira mais aprofundada, dada sua própria natureza estética e expressiva, as consequências da derrota política das esquerdas a partir de 1964 . Vistas em conjunto, algumas obras literárias formam um corpus que frequentemente tem sido esquecido pela memória social e pela história da cultura como síntese dialética entre derrota e resistência. Esta abordagem não significa a idealização do fazer literário, nem da "resistência", isentando-os de contradições e impasses estéticos e ideológicos. Curiosamente, a literatura não se tornou a base de uma memória hegemônica sobre a cultura do período. $\mathrm{Na}$ imprensa, termômetro da memória hegemônica sobre o período, quando se fala em cultura da resistência, abundam as referências a canções, peças de teatro e filmes, e faltam referências a obras narrativas ficcionais e poemas. Entretanto, reitero que a literatura ocupou um papel importante na resistência cultural principalmente em dois pontos: 1) no diagnóstico mais adensado e reflexivo da experiência social sob o autoritarismo e da violência; 2) no exame das contradições e impasses do intelectual de esquerda que se opunha ao regime militar.

Destaco, inicialmente, dois romances publicados nos primeiros anos após o Golpe, que são paradigmáticos na expressão da crise e do dilema dos intelectuais dentro do contexto autoritário. Neste sentido, se destacam dois romances canônicos: Pessach, a travessia (Carlos Heitor Cony, 1966) e Quarup (Antonio Callado, 1967). Em ambos, o intelectual é forçado a despirse de suas roupagens sociais e aderir à luta efetiva contra o regime. Mas o fazem de maneira diferenciada, expressando não apenas as vicissitudes e posicionamentos dos dois autores, mas soluções estéticas e construções narrativas diferenciadas dentro do gênero "romance".

O romance Pessach - a travessia tem como base da narrativa o chamado às armas feito por volta de 1965, pelos grupos que se agregavam

\footnotetext{
3 PELLEGRINI, Tania. Gavetas vazias. Ficção e política nos anos 1970. São Carlos/São Paulo, EDUFSCAR/Mercado de Letras, 1996; FRANCO, Renato. Itinerário político do romance pós-64: a festa. São Paulo, Editora da UNESP, 1998; GINZBURG, Jaime. "A ditadura militar e a literatura brasileira: tragicidade, sinistro e impasse". IN: SANTOS, Cecilia Macdowell; TELES, Edson; TELES, Janaina de Almeida. (orgs.).Desarquivando a Ditadura. Memória e Justiça no Brasil. São Paulo: Hucitec, 2009, v. 2, p. $557-568$

${ }^{4}$ SCHWARZ. R. "Cultura e política" In: O pai de família e outros estudos. Paz e Terra, 1992 (2.ed), p. 80 232| D O S S I Ê : LITERATURA E MEMÓRIA
} 
em torno de Leonel Brizola. No livro, um intelectual existencialista e libertário, crítico do padrão militarizado de militância dos grupos guerrilheiros, adere à guerrilha menos como um ato de crença ideológica e mais como um ato de liberdade de pensamento. A narrativa passa por várias peripécias nas quais o herói se afirma como habilidoso guerrilheiro e amante impetuoso. Ao final da jornada, mesmo com a guerrilha derrotada, o intelectual se mantém íntegro, realizando sua passagem pela história sem render-se a qualquer tipo de concordata moral diante do seu tempo. A autoimagem indulgente $e$ heroica do intelectual, amante, pensador $e$ guerrilheiro, a bem da verdade, pouco expressa a condição real do intelectual progressista após o golpe enquanto expressão documental de sua atuação social. Por outro lado, Pessach expressa uma vontade de protagonismo e um protagonismo real do intelectual engajado que não abre mão de sua liberdade existencial. As ilusões e contradições da obra são sintetizadas em uma crítica de bastante impacto à época do lançamento do romance, escrita por Paulo Francis, então um intelectual de esquerda ${ }^{5}$ :

Cony estabelece a absoluta incompatibilidade do intelectual com as linhas mestras da sociedade brasileira (...) o 'herói' se contempla e vê o próximo com precisão e lucidez, mas não passa disto (...) Diante da solução revolucionária que lhe é proposta por dois tipos a quem despreza pessoalmente, o protagonista manifesta um tom cético, fundado não só em razões de temperamento como na descrença da viabilidade dos esquemas em ação da esquerda local.

Transmutando os impasses do personagem ficcional para a condição histórica efetiva dos intelectuais brasileiros, ao se referir ao autor Cony, Francis arremata ${ }^{6}$ :

Seu individualismo continua intransigente, mas ele incorporou à personalidade um senso impessoal de alternativa, onde forças coletivas podem afirmar-se (...) os intelectuais são uma espécie de sismógrafo social (...) em países subdesenvolvidos onde a maioria vive em condições adequadas à era da Pedra Lascada, eles são muitas vezes forçados a deixar seus gabinetes e agir como vanguarda na humanização dos oprimidos.

Em outro romance de grande sucesso da época - Quarup, de Antonio Callado - o intelectual, representado pelo personagem altamente dilemático do padre Nando, segue outro caminho existencial e político. O lugar de chegada é o mesmo de Pessach: a guerrilha. Ao longo do livro, como

\footnotetext{
${ }^{5}$ FRANCIS, Paulo. "A travessia de Cony". Revista Civilização Brasileira., 13, 1967. p.179-183

${ }^{6}$ Idem, p. 183

233| D O S S I Ê : LITERATURA E MEMÓRIA
} 
destacou Ferreira Gullar, o intelectual se "deseduca" no contato com as classes populares, despojando-se das sutilezas e contorcionismos do pensamento especulativo para aderir à luta armada, que, no entanto, não é objeto da narrativa literária. Gullar, à época ligado ao PCB e, portanto, pouco simpático à opção política da luta armada, reconhece que a dimensão política do livro vai além da questão estrita da opção pela guerrilha ${ }^{7}$ :

\begin{abstract}
Pode-se discutir se o único caminho de reintegração do intelectual brasileiro é o seguido finalmente pelo Padre Nando e mesmo se a melhor maneira de lutar contra a opressão é essa a qual ele adere. Mas este é o aspecto episódico da questão: o fundamental é a afirmação implícita no romance, de que é preciso deseducar-se, livrar-se das concepções idealistas alheias à realidade nacional, para poder encontrarse (...) dentro do mundo que o romance define a realidade pessoal deságua no coletivo. Não se trata de apagar-se na massa, mas entender que o seu destino está ligado a ela, de encontrar um "centro.
\end{abstract}

Habilmente, ao definir a trajetória do Padre Nando, Gullar define o ideal de resistência intelectual dos comunistas, desviando a exortação política da luta armada que eventualmente poderia sobressair da leitura de Quarup ${ }^{8}$.

O peculiar lugar da literatura (e, por extensão, da cultura) no campo da resistência foi sugerido pela formulação crítica de Roberto Schwarz. Guiado pelo herói camponês, Padre Nando vai em busca do povo" "em cuja luta irá se integrar - com sabedoria literária" - num capítulo posterior ao último do livro" . Ao dizer que a sabedoria literária se expressa em uma luta que só pode se realizar para além do livro, Schwarz nos dá uma pista sobre um papel ainda pouco explorado acerca do papel da literatura naqueles tempos. Mais do que se confundir com a resistência em si, o fato literário, e a produção cultural como um todo, se realiza em sua negatividade, como exercício de desnudamento da consciência do narrador-leitor diante das efetivas contradições do mundo. Só a partir deste movimento, traumático e reflexivo, é que a "sabedoria literária" pode se exercitar como resistência efetiva. O problema central do romance Quarup, e do senso crítico que lhe dava

\footnotetext{
${ }^{7}$ GULLAR, Ferreira. "Quarup ou ensaio de deseducação para brasileiro virar gente". Revista de Civilização Brasileira, 15, 1967, p.25l-258

${ }^{8}$ Pessach - A travessia, desde sua primeira edição em 1967, esteve no centro de uma polêmica envolvendo Cony e alguns intelectuais que formavam o "Comitê Cultural" do Partido Comunista Brasileiro no Rio de Janeiro, como Ferreira Gullar e Leandro Konder (autor da orelha da primeira edição). Cony acusou os membros do Comitê de terem tentado boicotar o livro e o autor, tendo em vista que ambos não seguiam a cartilha do PCB. Konder negou tal "censura", dizendo apenas que Cony digerira mal as críticas e polêmicas em torno de suas posições políticas e literárias. Cony reiterou sua crítica aos comunistas anos depois no jornal O Globo (27/3/1997), por ocasião da 3edição de Pessach. Para maiores detalhes sobre este episódio ver KUSHNIR, Beatriz. "Depor as armas - a travessia de Cony e a censura no Partidão" IN: REIS Filho, Daniel A. (org.). Intelectuais, história e política. Rio de Janeiro, 7 Letras, 2000, p. 219-246

${ }^{9}$ RIDENTI, Marcelo. Em busca do povo brasileiro. Rio de Janeiro, Ed. Record, 2000

${ }^{10}$ SCHWARZ. R. "Cultura e política" In: O pai de família e outros estudos. Paz e Terra, 1992 (2.ed), p. 92

234| D O S S I Ê : LITERATURA E MEMÓRIA
} 
suporte, não era narrar a luta armada e afirmar o intelectual como herói da resistência (como em Pessach), mas examinar o processo de adequação da consciência do intelectual revolucionário aos novos tempos. Neste processo reflexivo, a própria figura do intelectual perdia sentido como herói político ou literário, pois só valia se diluída na luta maior que se travava, para além da obra de arte: a guerrilha.

Esta visão parece destoar da historiografia e da memória social que fetichizou a cultura e arte sob a ditadura como uma ação de resistência autoindulgente e encerrada em si mesma. Por outro lado, coloca a arte em uma situação de impasse: ou ela se faz exercício dialético do desnudamento dos véus entre consciência e mundo, supondo uma totalidade crítica do ser, ou ela naufraga na impostura e na autoindulgência. Em outra direção, podemos entender a literatura e a arte como expressão de contradições do ser social no labirinto de opções e dilemas políticos colocados pela história.

\section{Prosa ficional nos "anos de chumbo"}

Nos anos 1970, à medida que os impasses políticos causados pela derrota da guerrilha se tornavam patentes, bem como a visão de que os militares no poder não eram um evento provisório na história brasileira, o lugar do intelectual era redimensionado como eixo da "resistência cultural". O intelectual letrado fora duramente questionado na segunda metade dos anos 1960, seja em função de suas ilusões e impotências políticas no pósgolpe, seja por conta de sua inutilidade social na ótica das organizações guerrilheiras ("Morra o intelectual para nascer o revolucionário", dizia um dos slogans da época). Mas paradoxalmente, a década de 1970 lhe abria novas perspectivas de atuação profissional e política, em alguns casos nada confortáveis para aqueles que se viam como opositores do sistema, à medida que muitos intelectuais de esquerda foram tragados para dentro dos sistemas e instituições socialmente reconhecidos, como a imprensa, o mercado editorial e as universidades. Mesmo as diatribes da contracultura e seu antiintelectualismo faceiro, não chegaram a comprometer este novo lugar sistêmico do intelectual, situado entre a inserção profissional e a resistência política.

Este novo lugar social do intelectual teve um efeito particularmente adensado na criação literária, arte por excelência dos setores mais escolarizados e letrados da sociedade. A "crise do romance" como forma central de expressão da consciência literária e totalizante do mundo foi o resultado destes novos impasses. Ela é sintomática da crise do intelectual 
como "homem-de-letras" arauto das consciências, posto que tal como o narrador clássico do romance, os intelectuais pensavam o mundo, mas não se pensavam no mundo. Ao mesmo tempo, o regime militar renovava sua vigilância censória ao campo literário, com a edição do Decreto 1077, tratava da censura a livros, até então uma atividade menos sistemática do que a censura ao teatro, cinema e canções ${ }^{11}$.

A resposta criativa aos impasses estético-ideológicos e ao cerco da censura veio na forma de certa fragmentação da linguagem e do fluxo narrativo que é própria ao gênero, exercitado na prosa ficcional e também na poesia. Ao lado da forma "conto", estas variáveis expressivas da literatura tiveram papel de destaque ao longo dos anos 1970.

A obra de Érico Veríssimo, Incidente em Antares, apresentada em formato mais clássico, como expressão de denúncia da violência do autoritarismo, seria uma das últimas expressões mais vigorosas de literatura da resistência que mantinha um padrão formal calcado no romance ${ }^{12}$. Ainda assim, sua matéria realista é temperada pelo tom fantástico, que faz os mortos irromperem no dia a dia de uma pequena cidade para denunciar as mazelas e contradições dos vivos. Renato Franco destaca justamente o livro de Veríssimo, além de Sargento Getúlio (João Ubaldo Ribeiro, 1971) e As Meninas (Lígia Fagundes Telles, 1973) como obras que recusam, do ponto de vista formal e temático, a adesão à "cultura da derrota" e à crise do romance como sua expressão ${ }^{13}$.

Os livros de Antonio Callado dos anos 1970 - Bar Don Juan (1970) e Reflexos do Baile (1977) talvez sejam os mais exemplares na homologia entre fragmentação da consciência e da linguagem diante de um processo histórico de desagregação de um projeto político de resistência armada. Se em Quarup a crise da consciência totalizante, histórico-literária, do protagonista central e seus coadjuvantes se recompõem na forma de uma opção igualmente totalizante de enfrentamento - a luta armada - nos livros acima citados a linguagem não confirma a capacidade de recompor a consciência e a ação sobre o mundo. Em Bar Don Juan as cenas e diálogos apontam para uma percepção fragmentada e até certo ponto alienada do mundo, por parte daqueles que pretendiam enfrentar o regime, expressando um paroxismo que punha em dúvida as certezas éticas e políticas da esquerda. Em Reflexos do Baile - não por acaso um "romance" epistolar - o dialogismo dos pontos de vista, exacerbados em sua subjetividade fragmentada, não mais encontram

\footnotetext{
${ }_{11}^{11}$ REIMÃO, Sandra. Repressão e resistência. Censura a livros na Ditadura Militar. São Paulo, EDUSP/FAPESP, 2011

${ }^{12}$ Para uma análise mais aprofundada de Incidente em Antares como expressão da resistência ao regime ver PELLEGRINI, Tania. Gavetas Vazias. Ficção e Política nos anos 1970. Mercado de Letras / Editora UFSCAR, 1996, p. 61-120

${ }^{13}$ FRANCO, Renato. O romance na era do Terrorismo de Estado no Brasil (1964-1979), digit, s/d. p.8

236| D O S S I Ê : LITERATURA E MEMÓRIA
} 
um ponto de fuga comum onde pudessem se agregar e oferecer uma consciência coerente da realidade. Não por acaso, a última carta que fecha o livro expressa a perspectiva da repressão, na boca de um agente policial, cuja frieza protocolar parece ser a única possibilidade de compreensão - ainda que às avessas - do processo histórico em curso. A derrota da luta armada parecia enterrar a possibilidade de compreensão da lógica do mundo e das formas de atuar nele.

Em outra direção estética, mas apresentando resultados semelhantes do ponto de vista da impossibilidade de combinar consciência literária, ética humanista e ação política redentora, aparece Zero, de Loyola Brandão (finalizado em 1971, lançado em 1974 na Itália, em 1975 no Brasil, mas proibido no ano seguinte até 1979) ${ }^{14}$. A crise de valores políticos e da estrutura formal da narrativa, se radicaliza na linguagem crua, temperada com cenários e personagens alegorizados, que se rende à narrativa da violência direta como única matéria possível a ser moldada pelo narrador. Neste e em outros trabalhos do escritor, a relação entre os indivíduos de grupos sociais e formações intelectuais diferentes ("intelectuais e povo") não surge como possibilidade histórica, restando a violência entrecruzada e a desconfiança mútua, que desestrutura a própria linguagem ${ }^{15}$.

Mesmo quando o realismo deu o tom de outras respostas literárias dos anos 1970 à ditadura, evitou-se uma visão onisciente do narrador. O diálogo com o cinema documental e com o jornalismo, como forma de dinamizar a abordagem do real, aparece nos clássicos Em Câmara Lenta (de Renato Tapajós, 1977) e A Festa (de Ivan Angelo, 1976). Aliás, o princípio da montagem, conforme Renato Franco, seria uma das marcas da literatura de resistência a partir da segunda metade dos anos $1970^{16}$. Essa ruptura de procedimento criativo não é mero detalhe estilístico, e pode revelar a necessidade de um "terceiro olho", como diria Benjamin, uma perspectiva de sobrevisão em relação ao mundo que superaria os limites impostos pela crise da consciência do intelectual narrador-personagem, mas sem cair no exercício lírico e subjetivo que aproximaria a prosa da poesia.

Em ambos os livros, não há vestígios de qualquer "boa consciência literária" do intelectual que esteve na origem da própria ideia de resistência cultural, embora se consagre a palavra literária como caminho para desentorpecer a consciência social. A narrativa sobre violência da repressão é

\footnotetext{
${ }^{14}$ Para uma análise detalhada de Zero, ver PELLEGRINI, Tania. Gavetas Vazias. Ficção e Política nos anos 1970. Mercado de Letras / Editora UFSCAR, 1996, p.128-169

${ }^{15}$ FRANCO, Renato. O romance de resistência nos anos 1970. XXI Congresso Internacional da Associação de Estudos LatinoAmericanos. September 24-26, 1998, Chicago, IL, lasa.international.pitt.edu/LASA98/Franco.pdf, p. 6

${ }^{16}$ FRANCO, Renato.Itinerário político do romance pós-64: a festa. São Paulo, Editora da UNESP, 1998. 237| D O S S I E : LITERATURA E MEMÓRIA
} 
a base para uma consciência que reconhece o "círculo do medo" que envolvia a sociedade, sob a ditadura triunfante. Em Câmara Lenta expressa um narrador (com fortes traços da experiência do autor) que destila sua indignação diante da morte vil sob tortura da companheira de armas, como forma de superar traumas e de recompor a narrativa de uma violência siderada e absurda da repressão ${ }^{17}$. Ao longo do livro, a possibilidade de narrativa do momento-chave da experiência traumática - a morte sob tortura - é construída de maneira enviesada, melancólica, aproximativa, que aos trancos, só se completa no final, como num esforço quase psicanalítico ${ }^{18}$. Neste processo narrativo que moldava a matéria histórica, humanizava-se a violência reativa do guerrilheiro e mantinha-se seu heroísmo e dignidade, mesmo na derrota. Já em Festa, a dignidade e o heroísmo estão ausentes. Os inúmeros personagens, sobre os quais não predomina propriamente um ponto de vista, são tratados como notícia de jornal, linguagem quase descritiva que tenta recompor os mosaicos de uma sociedade fragmentada e autofágica, à mercê de um terrorismo de Estado que vai muito além da repressão direta a guerrilheiros, chegando ao cidadão comum que se pensava imune à repressão. A ditadura era triunfante à medida que tinha se enraizado no cotidiano, na vida privada, produzindo culpados dentro da sua lógica de vigilância e disseminando uma lógica de violência que ia além dos porões.

\section{Poesia nos "anos de chumbo"}

O campo da poesia, por outro lado, parece não se enquadrar no axioma de criação literária enquanto lapidação de uma consciência da derrota e aproximação de um real por um sujeito que se vê em meio a um labirinto sem possibilidade de uma narrativa totalizante. A lírica e a consciência poética, arrisco dizer, debruçam-se mais diretamente sobre a relação entre linguagem e ser (social), deslocando os sentidos e silêncios impostos pelos discursos dominantes das ditaduras ${ }^{19}$. Os fragmentos de consciência histórica nas principais expressões poéticas dos anos 1970 enfrentaram o tema da derrota ou através de um olhar enviesado, que dessacralizava a vitória da

\footnotetext{
${ }^{17}$ Para uma história das peripécias da edição do livro, que em si constituem um evento de resistência, ver ARAGÃO, Eloisa. Censura na lei e na marra. Como a ditadura quis calar as narrativas sobre suas violências. São Paulo, FAPESP/HUMANITAS, 2013

${ }^{18}$ COSTA, Carlos Augusto. Como um corte de navalha: resistência e melancolia em Em câmara lenta", de Renato Tapajós. Dissertação de Mestrado em Literatura Brasileira, 2011

${ }^{19}$ Alfredo Bosi bem sintetizou a relação mediada e sutil entre poesia e política, independente do tema específico do poema remeter a qualquer tipo de exortação explícita: "Projetando na consciência do leitor imagens do mundo e do homem muito mais vivas e reais do que as forjadas pelas ideologias, o poema acende o desejo de uma outra existência, mais livre e mais bela. (...) A poesia traz, sob as espécies da figura e do som, aquela realidade pela qual, ou contra a qual, vale a pena lutar." (BOSI, A. O ser e o tempo da poesia. São Paulo, Companhia das Letras, 2000, $6^{a}$ ed, p. 227

238| D O S S I Ê : LITERATURA E MEMÓRIA
} 
ditadura pela linguagem do humor, ou enfrentava os impasses da subjetividade colapsada pela experiência histórica objetiva do "círculo do medo". Arrisco dizer que, livres do imperativo de pensarem o lugar do intelectual como agente histórico e ator político, as expressões poéticas dos anos 1970 se debruçaram mais sobre a linguagem como caminho de uma nova lírica para compreender o real (e seus absurdos), refazendo, com "sabedoria literária" as tessituras que davam sentido à história.

O humor não esteve ausente dos poemas, ao contrário do que se vê na prosa. A ironia aqui mobilizada procurava desnudar o absurdo da situação política do país e as próprias insuficiências de uma narrativa organizada e mimética para dar conta da experiência histórica ${ }^{20}$. Assim, a poesia se fez resistência como expressão destiladora dos sentimentos coletivos (medos, afetos, paixões), como descoberta e reinvenção de um mundo, como crítica da "desordem estabelecida", afirmando o imperativo da subjetividade como sobrevivência dos valores ameaçados pela experiência histórica do autoritarismo e da violência de Estado ${ }^{21}$.

O grupo de poetas identificados com chamada a "Poesia Jovem" ou "Geração 70" (ou ainda, "Geração Mimeográfo) apostaram na fragmentação da linguagem e no afastamento de temas "realistas" como forma de estimular a revisão da consciência de mundo. Conforme Heloisa Buarque, a poesia da Geração 70 foi uma resposta direta aos tempos históricos sombrios:

Assim, poesia e vida se casavam promovendo uma prática que, longe de ser pacífica, tentava com vigor crítico algumas respostas ao momento negro que experimentávamos. Surge uma multidão de poetas, cria-se um público, inventam-se formas independentes de produção, distribuição e veiculação para a literatura. A alegria e o humor como guerrilha. (...) É possível se pensar a poesia marginal dos anos 70 em várias direções. Fico aqui com um de seus aspectos: um espaço de resistência cultural, um debate político. Em pleno vazio, os jovens - e os não tão jovens - põem em pauta os impasses gerados no quadro do Milagre e desconfiam progressivamente das linguagens institucionalizadas e legitimadas do Poder e do Saber (...) A crítica social mais ligada ao cotidiano e à individualidade foi, inegavelmente, um avanço em termos do debate cultural e político, além de responder, com eficácia, ao sentimento generalizado de falência e de fracasso que os 70 conheceram 22

\footnotetext{
${ }^{20}$ Vide, por exemplo, o poema Grupo Escolar (Cacaso): Sonhei com um general de ombros largos / que fedia / e que no sonho me apontava a poesia / enquanto um pássaro pensava suas penas / e já sem resistência resistia./ O general acordou e eu que sonhava / face a face deslizei à dura via / vi seus olhos que tremiam, ombros largos, / vi seu queixo modelado a esquadria /vi que o tempo galopando evaporava / (deu pra ver qual a sua dinastia) /mas em tempo fixei no firmamento / esta imagem que rebenta em ponta fria / poesia, esta química perversa /este arco que desvela e me repõe / nestes tempos de alquimia

${ }_{21}$ BOSI, Alfredo. O ser e o tempo na poesia. São Paulo, Companhia das Letras, 2000 (6 ed), p. 167

${ }^{22}$ Jornal do Brasil, Caderno B - Rio de Janeiro, sábado, 13 de dezembro de 1980. Heloísa Buarque de Hollanda DEPOIS DO POEMÃO (http://www.sbpcnet.org.br/saoluis/arquivos) 
O humor, o descompromisso e a leveza de uma consciência amena do real $^{23}$ dividem espaço com expressões mais sombrias das crises de identidade e da falta de perspectiva, sobretudo para a juventude mais consciente do seu lugar na história. O slogan, a linguagem da mídia, o hai-kai e a pichação, formas moleculares de escrita que pautam a poesia jovem, não expressam apenas um lirismo autocentrado, mas propõem um jogo coletivo e lúdico de proposições poéticas cuja força está exatamente no pronto reconhecimento e no deslocamento da linguagem. Paulo Leminski, um dos ícones da geração, sintetizou esta perspectiva: "A chamada poesia marginal dos anos 70 é uma poesia, em grande parte ignorante, infanto-juvenil, tecnicamente inferior aos seus antecessores. ${ }^{124}$.

Apesar deste esvaziamento da labuta com a palavra e da busca do sublime, a crítica literária percebeu o potencial da poesia como expressão de uma nova consciência, não totalizante, de mundo, afirmação de uma subjetividade como expressão de consciência nostálgica, lírica ou utópica ${ }^{25}$ ou atitude farsesca dessacralizadora dos rigores da ditadura ${ }^{26}$. Em outras palavras: Expressão de uma crise estética e política, mas vontade de superá-la, poeticamente.

Obviamente, não devemos generalizar, pois mesmo no campo da "poesia jovem", o sentido lírico e trágico de uma subjetividade massacrada pela realidade está presente, como no poema canônico "Cogito" de Torquato Neto que pode ser visto como o testamento trágico de uma juventude encapsulada entre a vocação para a plenitude existencial e a partilha de uma melancolia histórica:

Eu sou como eu sou
pronome
pessoal intransferível
do homem que iniciei
na medida do impossível
eu sou como eu sou
agora
sem grandes segredos dantes
sem novos secretos dentes
nesta hora
eu sou como eu sou
presente

\footnotetext{
${ }^{23}$ vai ter uma festa / que eu vou dançar / até o sapato pedir pra parar / aí eu paro, tiro o sapato / e danço o resto da vida (Rápido e Rasteiro, Chacal)

${ }^{24}$ Correio das Artes. João Pessoa, PB, 8/7/84), de João Pessoa Apud FORTUNA, Felipe. O que ficou da poesia marginal? Jornal do Brasil, Caderno B/Especial, 07 de setembro de 1986 (Disponível em: http://acd.ufrj.br/pacc/literaria/oqueficou.html)

${ }^{25}$ BOSI, A, "Poesia e resistência" In: O ser e o tempo na poesia. São Paulo, Companhia das Letras, 2000 (6 $\left.{ }^{a}\right)$, p.167

${ }^{26}$ HOLLANDA, Heloisa B. Impressões de viagem. CPC, Vanguarda e desbunde. São Paulo, Brasiliense, 1981 
desferrolhado indecente

feito um pedaço de mim

eu sou como eu sou

vidente

e vivo tranquilamente

todas as horas do fim

Entretanto, o poema mais impactante dos anos 1970, ao menos para a crítica literária, não veio da poesia "jovem", "marginal" ou da "geração mimeógrafo". Em 1975, com Poema Sujo, Ferreira Gullar, desde o exílio em Buenos Aires, fundiu a memória, a história e a sensação de decadência e impotência que transformava a cidade e o poeta em ruinas de um projeto abortado de mundo e subjetividade, confrontadas pelos dilemas da história, mas igualmente se afirmando como exercício de superação ${ }^{27}$. Conforme Viviana Bosi:

No Poema sujo realiza-se um envolvimento agora visceral com a dimensão coletiva social, que foi processada substancialmente e passou a entrar de igual pra igual na linguagem lírica, porque esta se alargou para recebê-la. O exílio levou o poeta a expressar uma subjetividade solitária mas, paradoxalmente, através do afeto e da memória, agora sim múltipla e solidária28

José Paulo Paes, que não se dedicou propriamente à poesia engajada, também deixou uma pequena e deliciosa troça poética sobre a ditadura, que nada devia ao humor dos "poetas jovens", como por exemplo, em Seu Metaléxico:

Economiopia / Desenvolvimentir/ Utopia / Consumidoidos/ Patriotários/Suicidadãos"

(Seu Metaléxico, poema de Meia Palavra).

Outro poeta que dialogou com a "geração mimeografo", mas transpôs seus limites formais e temáticos, foi Francisco Alvim. Ainda conforme Viviana Bosi: "Seus poemas dos anos 70 e 80 acusam os porões da ditadura, ao insinuar a tortura, o medo e a perseguição, sugerindo a corrupção e o apadrinhamento, muitas vezes de forma velada, figurando situações ambíguas

\footnotetext{
${ }^{27}$ Logo depois do Golpe, diga-se, a poesia de Gullar já apontava para os impasses subjetivos diante da história, como em Madrugada: Do fundo de meu quarto, do fundo de meu corpo clandestino ouço (não vejo) ouço crescer no osso e no músculo da noite a noite a noite ocidental obscenamente acesa sobre meu país dividido em classes (Dentro da noite veloz, 1962-1974). Sobre as matérias poéticas e procedimentos criativos da poesia de Gullar ver: VILLAÇA, Alcides. A poesia de Ferreira Gullar. Tese de Doutorado. São Paulo, FFLCH-USP, 1984

${ }^{28}$ BOSI, Viviana. “A poesia e a política são demais para um só homem”. Revista Maracanan, n.11, Dezembro 2014, p. 10-23, p. 13.

Disponível em: http://www.e-publicacoes.uerj.br/index.php/maracanan/article/view/14037
} 
que precisam ser decodificadas pelo leitor. A autora destaca o poema "Postulando" (Passatempos, 1974):

A primeira providência é ver se há um cargo Se tiver, ele há de querer entrevistá-lo Ao meio-dia o candidato estará aqui o senhor querendo ficarei também para recebêlo $\mathrm{O}$ telegrama dizia porque meu nome não fora aprovado razões de segurança, denúncia de um amigo que virou meu inimigo Foram corretos comigo deixaram-me ver o telegrama / Não entendi Dois meses antes me haviam chamado de volta para responder o inquérito Saí limpo Ainda comentaram passou no exame, meu velho É bom que você saiba que tenho de fazer a consulta Um dia desses por que não saímos?

O tom prosaico e banal do diálogo exacerba o lado absurdo da vigilância política, transformando o cotidiano em prisão, o local de trabalho em antro da corrupção, a entrevista em inquérito, o ex-amigo em inimigo que denuncia. É o exercício da linguagem dialógica e não propriamente a linguagem como expressão lírica do sujeito diante do mundo que denota o absurdo do autoritarismo em sua busca por culpados e subversivos ${ }^{29}$.

\section{Uma nota sobre a literatura de não-ficcão}

A literatura de não-ficção, que não será abordada de maneira mais abrangente nos limites deste artigo, foi responsável pela dinamização do mercado editorial no Brasil, sobretudo a partir de $1975^{30}$. Esta tendência pode ser encontrada na febre de "romance-reportagem" (Aguinaldo Silva, José Louzeiro) e de livros de memórias, sobretudo após 1979, quando os exilados começam a voltar e a narrar suas aventuras e desventuras na luta contra o regime militar e no exílio ( $O$ que é isso, companheiro? e Os Carbonários, escritos pelos ex-guerrilheiros Fernando Gabeira e Alfredo Sirkis). Já no ocaso da ditadura, o grande sucesso de Feliz Ano Velho (Marcelo Rubens Paiva, 1982) reafirmava o caminho das narrativas memorialísticas, entrecruzando as vítimas diretas e indiretas da violência do regime neste caso, como caminho literário para se compreender o impacto da ditadura sobre indivíduos e sobre a sociedade, e particularmente sobre a juventude que cresceu sob o AI-5.

Ao que parece, estes gêneros de "não-ficção" ocuparam o espaço deixado pelo romance como "narrativa sobre o mundo" a partir de uma

\footnotetext{
${ }^{29}$ Outros trechos de poemas de Alvim, publicados em 1978, com alusões à ditadura: "Onde a lei não cria obstáculos/ coloco labirintos" ("Autoridade") / "Nosso negócio é a tortura/ sempre que falarem o nome dele/ invente" ("Conselho") / "Aqui a gente sai/ e não sabe se volta" ("Voltas") / "Vamos viver a era do centauro/ metade cavalo/ metade também" ("Meu filho").

${ }^{30}$ Neste ponto, destaco o trabalho de Flamarion Maues: MAUES, Flamarion. Livros contra a ditadura. Editoras de oposição no Brasil (1974-1984). São Paulo: Publisher, 2013

242| D O S S I Ê : LITERATURA E MEMÓRIA
} 
consciência que conhece o sentido do processo e dos fatos ao redor dos personagens. Se o "romance-reportagem", em flerte com o estilo new journalism tenta dar sentido a eventos que traduzem a mazela de uma sociedade atravessada pela violência do Estado e pela corrupção e amoralidade, os livros de autobiografia são marcos de reconstrução da memória, principalmente sobre a experiência da guerrilha, seu impacto na sociedade e seu lugar na história do Brasil ${ }^{31}$. Foram gêneros literários muito significativos do período da Abertura e expressam a necessidade de balanço e compreensão histórica de um período que parecia ter passado e que se configurava como dois momentos distintos, porém complementares: 1) as "utopias" dos anos 1960 e 2) a dura realidade da repressão dos "anos de chumbo".

As "consciências literárias" construídas durante o regime militar percorrem um movimento reconhecível no tempo que vai da reflexão sobre a derrota, tendo o intelectual de esquerda como personagem e narrador pleno, à busca de uma nova expressão, em prosa e poesia, que olha para o mundo de maneira oblíqua, fragmentada e enviesada. A primeira fase deste movimento seria a marca dos primeiros anos após o golpe, enquanto o segundo momento marcaria a literatura dos "anos de chumbo". Ainda poderíamos ver um terceiro momento da relação entre literatura e ditadura, que se configura a partir do final da década de 1970, pautado pela a literatura de testemunho e pelos livros de não-ficção (ainda que muitos tenham sido escritos em diálogo com estilos literários, como o "romance-reportagem").

Finalizo este artigo com o reconhecimento de que a relação entre literatura e ditadura é multifacetada e complexa, e não cabe em esquemas interpretativos e periodizações históricas rígidas. Aqui, trata-se de pensar algumas tendências, sem prejuízo da análise individual das obras que deram respostas plurais e variadas para os mesmos dilemas e impasses históricos proporcionados pela experiência social do autoritarismo. É preciso também reconhecer que a relação entre literatura e ditadura não acabou em 1985, quando, convencionalmente, diz-se que o regime dos generais chegou ao fim. As questões não resolvidas, os traumas e tabus individuais e coletivos decorrentes daquela experiência, a matéria da violência como propulsora da narrativa literária ${ }^{32}$, e os jogos da memória sobre aquele "passado que não passa" ainda alimentam, e alimentarão, a criação literária brasileira ${ }^{33}$.

\footnotetext{
${ }^{31}$ ROLLEMBERG, Denise. "Esquecimento das memorias". In: MARTINS FILHO, João Roberto. O golpe de 64 e o regime militar: novas perspectivas. São Carlos, Ed. UFSCAR, 2006, p. 81-92; SELIPRANDY, Fernando. A luta armada no cinema. São Paulo, Ed. Intermeios, 2015.

${ }^{32}$ GINZBURG, Jaime. Crítica em tempos de violência. São Paulo, EDUSP, 2012

${ }^{33}$ Ver, por exemplo: KUCINSKI, Bernardo. K. São Paulo, Expressão Popular, 2014; BRACHER, Beatriz. Não falei. Editora 34, 2012; FUKS, Julian. A Resistência. São Paulo, Companhia das Letras, 2015.

243| D O S S I Ê : LITERATURA E MEMÓRIA
} 